\title{
Proteomic analysis reveals overexpression of moesin and cytokeratin 17 proteins in colorectal carcinoma
}

\author{
CHAN YONG KIM ${ }^{1}$, WOON YONG JUNG ${ }^{2}$, HYUN JOO LEE ${ }^{2}$, \\ HAN KYEOM KIM ${ }^{2}$, AEREE KIM ${ }^{2}$ and BONG KYUNG SHIN ${ }^{2}$ \\ ${ }^{1}$ Department of Pathology, Korea University College of Medicine, Seongbuk-ku, \\ Seoul 136-701; ${ }^{2}$ Department of Pathology, Korea University College of Medicine, Korea \\ University Guro Hospital, Guro-gu, Seoul 152-703, Republic of Korea
}

Received September 5, 2011; Accepted October 20, 2011

DOI: $10.3892 / o r .2011 .1545$

\begin{abstract}
The study of tumor biomarkers was gradually facilitated by the adoption of proteomic strategies due to less invasiveness and higher sensitivity. Colorectal cancer is one of the most commonly occurring cancers worldwide and its incidence has markedly increased in Korea. While the adoption of proteomic strategies facilitated the study of tumor biomarkers, to date, no common agreement has been derived from proteomic investigations regarding tumor markers of colorectal cancer. This study was designed to find molecules differentially expressed in colorectal cancer compared to non-tumor mucosa. Four colorectal adenocarcinoma and corresponding non-tumor tissue samples were analyzed to find previously unknown proteins via two-dimensional electrophoresis and MALDI-TOF/MS spectrometry. Western blot assays and tissue microarray (TMA) immunohistochemistry were performed to validate the identified proteins. Among the twelve up-regulated and one down-regulated proteins identified, moesin, cytokeratin (KRT) 17 and carbonic anhydrase I were validated by Western blot analysis and/or immunohistochemistry. On immunohistochemistry, both moesin and KRT17 demonstrated a tendency of increased expression as pT stage advanced. Both moesin and KRT17 were not expressed in normal colorectal epithelium. These two proteins may play a role in cancer invasion and/or metastasis in colorectal carcinoma, and could be candidate biomarkers for the diagnosis and prognosis of colorectal cancer.
\end{abstract}

\section{Introduction}

The incidence of colorectal carcinoma has markedly increased in Korea (1). The increased incidence may be explained by

Correspondence to: Dr Bong Kyung Shin, Department of Pathology, Korea University College of Medicine, Korea University Guro Hospital, 80 Guro-dong, Guro-gu, Seoul 152-703, Republic of Korea E-mail: tabrega@korea.ac.kr

Key words: proteomics, 2-dimensional electrophoresis, mass spectrometry, colorectal carcinoma, moesin, cytokeratin 17 adoption of a westernized diet, decreased physical activity, smoking, and increased detection of early cancers due to the popularization of colonoscopic examination (1). According to the recent cancer statistics in Korea, the incidence of colorectal carcinoma is second to that of gastric cancer, being the second most common cancer in men and the third in women (http:// www.cancer.go.kr/cms/statics/incidence/index.html). Colorectal cancer is also the fourth leading cause of cancer-related deaths in Korea, after lung cancer, hepatocellular carcinoma, and gastric cancer (http://www.cancer.go.kr/cms/statics/mortality/41index. html). The relatively low mortality compared to the high incidence is considered partially due to the comparatively early manifestation of symptoms, and the easy diagnosis through colonoscopy and biopsy. However, death from tumor recurrence and/or metastasis after initial treatment is very common in colorectal cancer. Besides, in rectal cancer comprising a significant proportion of the colorectal cancer, the surgical treatment may be difficult in many cases and require the colostomy formation that may cause considerable discomfort and complication to the patient. Therefore, colorectal carcinoma has a remarkable influence on the lives of the patients and their families that is greater than expected from the simple comparison of the mortality rates. To decrease the mortality and minimize the complication, a lot of efforts have been made to develop the diagnostic tools for early cancer detection, to apply the neoadjuvant treatment for increasing the operability and decreasing the surgical complication, and to develop the targeted therapy for suppressing cancer recurrence or metastasis.

For the early detection of colorectal carcinoma, not only in symptomatic but also in asymptomatic patients, colonoscopy is currently the best method. However, despite the relatively low invasiveness of this tool, it is difficult to perform colonoscopy in every patient in the risk group because of the fastidious preparation, the discomfort and pain caused by the examination, and the high cost. Other attempts for simpler and more costeffective techniques have been tried, including, for example, the stool guaiac test for detection of invisible blood, and the test for detection of mutated DNA in stool (2-5). However, these techniques have not been proved to be effective in clinical practice or have too low specificity to replace the colonoscopic examination for the early detection of colorectal carcinoma. 
Concerning the treatment, besides the surgical resection and conventional chemotherapy, the two major strategies of current interest in clinical practice of colorectal carcinoma are the targeted inhibition of the epidermal growth factor receptor (EGFR) and the blocking of tumor angiogenesis. Cetuximab, the recombinant monoclonal antibody against the extracellular domain of EGFR, has improved the survival in patients whose tumors were resistant to previous conventional chemotherapeutic agents $(6,7)$. The angiogenesis inhibitor bevacizumab, a humanized VEGF blocking antibody, demonstrated a marked inhibition of tumor angiogenesis and tumor growth and is now widely used in clinical practice for the treatment (8-10). Other approaches for targeted therapy of colorectal cancer include the inhibitors of Src tyrosine kinases (11-14), mTOR (15) or PI3K (16,17), and molecules inducing apoptosis (18-22), and radioimmunotherapy using cancer-specific antibodies (23). However, the benefit from cetuximab and/or bevacizumab treatment is so limited that only a small proportion of patients respond to the drugs and their lifespan is increased by only a few months compared to those who only receive supportive care. In addition, no other targeted approach has produced a sufficiently satisfactory result in clinical trials. Although there is a good chance that some of the other candidates will further improve the treatment of colorectal cancer, a lot of work both in laboratory investigation and clinical trial needs to be done to achieve this goal.

So far, the approach for development of new target molecules for early detection and treatment of cancer has been focused on the molecular research on RNA, genomic DNA or complimentary DNA. The recently developed highthroughput technologies using a large population of samples and microarray techniques have detected various genetic alterations in cancer cells that may contribute to carcinogenesis. However, these genetic changes may not frequently be reflected in the phenotypic expression because, while the genetic information of DNA is transmitted through mRNA and then to protein molecules, various influences by molecules of different information and/or participating different signal transduction pathways can prevent the mutation or amplification of genes from their final expression in effector proteins. Because proteina are the final effector molecules in all cellular activity, including cell survival, proliferation, transformation, and apoptosis, the direct analysis of them by proteomics may achieve the goal of detecting critical molecules in development and progression of colorectal cancer, which may act as biomarkers for diagnosis, prognostic indication, prediction of treatment response, and/or treatment monitoring, which cannot be discovered by the genomic analysis alone. The proteomic approach for colorectal cancer biomarker discovery is actively under investigation. In cancer research, proteomics is used to compare the expression profiles of proteins in cancer and normal tissues and attempts to detect the specific proteins responsible for the characteristics of cancer tissue. Although many groups have reported various protein molecules up- or down-regulated in colorectal carcinoma as biomarker candidates through proteomic analysis, currently the sensitivity and/or specificity of these molecules are not satisfactory for clinical practice $(21,24-28)$.

In this study, we investigated the proteomic profile of colorectal cancer, by comparing it with that of non-tumor colorectal mucosa, in an attempt to identify proteins differentially expressed in cancer tissues. Then, by investigating the expression of the detected proteins in paraffin-embedded cancer tissues with variable clinicopathological characteristics, we tried to find proteins that may help to comprehend the biology of the development and progression of colorectal carcinoma and contribute to the development of reliable biomarkers of cancer diagnosis, prognosis, and/or treatment.

\section{Materials and methods}

Patients and samples. For proteomic analysis, fresh-frozen colorectal cancer and paired non-tumor tissue samples from 10 patients who underwent surgery in Korea University Guro Hospital, Seoul, Korea, between April 2006 and March 2009 were obtained from the Korea Lung Tissue Bank (KLTB) in the Korea University Guro Hospital. The samples had been collected within $1 \mathrm{~h}$ of surgical excision, quick-frozen in liquid nitrogen, and then transferred to and stored in a $-80^{\circ} \mathrm{C}$ freezer in KLTB. The clinicopathological data and glass slides for histological review were also provided by KLTB. All tumors had been diagnosed at the time of surgery as more advanced than stage IIB, being T4, according to the 6th AJCC cancer staging system. They were reviewed and confirmed before submission to the study.

To confirm the expression of the proteins detected in the proteomic analysis by immunohistochemistry, paraffin blocks of colorectal cancer and non-tumor mucosa from 176 patients who underwent surgery in the Korea University Guro Hospital between January 2002 and December 2004 were obtained from KLTB. The clinicopathological data, including age, gender, histological classification and TNM stage according to the 6th AJCC cancer staging system, were also provided from KLTB.

The study protocol was reviewed and approved by the Institutional Review Board of the Korea University Guro Hospital. All the samples and data from the KLTB had been collected after informed consents had been obtained from the participating patients.

Protein extraction and purification. Forty to fifty, $10-\mu \mathrm{m}$ cryostat sections were serially cut from each frozen tissue sample of about $8 \mathrm{~mm}^{3}$. Two or more inconsecutive sections were stained with hematoxylin and eosin (H\&E) to evaluate whether the sample contains sufficient tumor or normal epithelial cells for protein extraction without excessive necrosis or stromal fibrosis (Fig. 1). The remaining sections were put into a microtube and suspended immediately in $0.5 \mathrm{ml}$ of lysis solution containing $7 \mathrm{M}$ urea, $2 \mathrm{M}$ thiourea, 4\% 3-[(3-cholamidopropyl) dimethylammoniol]-1-propanesulfonate (CHAPS), 1\% DTT, $10 \mathrm{mM}$ protease inhibitor, and 2\% IPG buffer. Protein extraction was carried out on a vortex mixer at room temperature for $1 \mathrm{~h}$. After adding $10 \mu \mathrm{l}$ of DNase I, the solution was incubated for $30 \mathrm{~min}$ on ice, and centrifuged at $13,200 \mathrm{rpm}$ for $1 \mathrm{~h}$ at $15^{\circ} \mathrm{C}$. The supernatant was mixed 1:1 with $20 \%$ trichloroacetic acid for protein precipitation and then incubated at $-20^{\circ} \mathrm{C}$ for $2 \mathrm{~h}$ or more, observing the formation of whitish precipitate. After removing the supernatant, the protein precipitate was washed in precooled $-20^{\circ} \mathrm{C}$ acetone and then centrifuged again at 13,200 rpm for $20 \mathrm{~min}$ 
at room temperature. Removing the supernatant, the acetone washing was repeated and the precipitate was left on the clean bench till acetone was completely dried. The protein pellet was dissolved again in the lysis solution. The concentration of protein was measured by the Bradford method.

Two-dimensional gel electrophoresis (2-DE). For the first dimensional electrophoresis, i.e., isoelectrofocusing (IEF), $1,000 \mu \mathrm{g}$ of protein from the lysate was mixed with the rehydration solution (7 M urea, $2 \mathrm{M}$ thiourea, $1 \% \mathrm{CHAPS}, 0.4 \% \mathrm{DTT}$, $0.5 \%$ IPG buffer, and $0.002 \%$ bromophenol blue) to make a total volume of $450 \mu \mathrm{l}$. The mixed solution was applied to an Immobiline $^{\mathrm{TM}}$ DryStrip gel ( $\mathrm{pH}$ 3-10, 24 cm; GE Healthcare, Uppsala, Sweden) and incubated at room temperature for $12 \mathrm{~h}$ on level surface for rehydration and protein loading. Isoelectrofocusing was carried out at $-20^{\circ} \mathrm{C}$, first with linear voltage at $200 \mathrm{~V}$ for $1 \mathrm{~h}, 500 \mathrm{~V}$ for $1 \mathrm{~h}$, and $1,000 \mathrm{~V}$ for $1 \mathrm{~h}$, then with gradient voltage from 1,000 to $8,000 \mathrm{~V}$ for $3 \mathrm{~h}$ and then finally remaining at $8,000 \mathrm{~V}$ until the total $\mathrm{V}$-h value reached 52,000 .

The strips were then equilibrated sequentially in Buffer I (50 mM pH 8.8 Tris- $\mathrm{HCl}$ buffer containing 6M urea, 30\% glycerol, $2 \%$ SDS, $0.01 \%$ bromophenol blue and 1\% DTT) and Buffer II $(50 \mathrm{mM}$ pH 8.8 Tris- $\mathrm{HCl}$ buffer containing $6 \mathrm{M}$ urea, $30 \%$ glycerol, $2 \%$ SDS, $0.01 \%$ bromophenol blue and $4 \%$ iodoacetamide) each for $15 \mathrm{~min}$ at room temperature. Each strip was then placed on a $12.5 \%$ SDS-PAGE gel $(240 \times 200 \times$ $1 \mathrm{~mm}$ ) and separation in the second dimension was carried out in two steps: $5 \mathrm{~mA}$ for $2 \mathrm{~h}$ per gel and $27 \mathrm{~mA}$ for $7 \mathrm{~h}$ per gel in Ettan ${ }^{\mathrm{TM}}$ DALT six electrophoresis unit (GE Healthcare). All experiments were repeated three times for each sample.

Staining and image analysis. The gels were stained overnight in solution containing 34\% methanol, 3\% phosphoric acid, $10 \%$ ammonium sulfate and $0.12 \%$ Coomassie R250, and then washed with distilled water for more than $6 \mathrm{~h}$ until the protein spots were adequately revealed. The gels were scanned with ImageScanner (GE Healthcare). The digitized gel images were then analyzed and protein spots were detected by ImageMaster 2-D Platinum 6.0 software (GE Healthcare). The number of spots was automatically determined. The differentially expressed proteins between the cancer and non-tumor mucosa groups were selected based on the two normalized spot values, i.e., the $\%$ volume and the $\%$ intensity. The former was calculated as \% volume $=($ spot volume $/$ spot volumes of all spots resolved in the gel) $\mathrm{x} 100$ and the latter $\%$ intensity $=$ (spot intensity/spot intensities of all spots resolved in the gel) $\mathrm{x}$ 100. Proteins were considered as differentially expressed when the gap value of $\%$ volume, defined as the maximum difference between the range of the one group and the range of the other group), was positive or non-overlapping. Among the proteins with positive gap values, 13 spots with the most significant differences in $\%$ intensity were finally selected for mass spectrometry and protein identification (Fig. 2).

In-gel digestion and mass spectrometry. The selected spots were manually excised from gels, washed with distilled water, destained with a $6: 4$ mixed solution of $50 \mathrm{mM} \mathrm{NH}_{4} \mathrm{HCO}_{3}$ $(\mathrm{pH} 7.8)$ and acetonitrile and then dried by vacuum centrifugation. After adding $5 \mu \mathrm{l}$ of trypsin $(12.5 \mathrm{ng} / \mu \mathrm{l}$ in $50 \mathrm{mM}$
$\mathrm{NH}_{4} \mathrm{HCO}_{3}$ ) to each gel piece, in-gel digestion of protein was preceded on ice for $45 \mathrm{~min}$. After trypsin was removed, each gel piece was incubated with $50 \mathrm{mM} \mathrm{NH}_{4} \mathrm{HCO}_{3}$ for $12 \mathrm{~h}$ at $37^{\circ} \mathrm{C}$. The obtained peptide solution was applied onto a microcolumn packed with Poros $\mathrm{R} 2$ resin and washed with $2 \%$ formic acid. Adding 1-1.5 $\mu \mathrm{l}$ of matrix solution $[10 \mathrm{mg} / \mathrm{ml}$ $\alpha$-cyano-4-hydroxycinnamic acid (CHCA) in $70 \%$ acetonitrile and $2 \%$ formic acid] to the column, the eluted peptides were loaded onto the MALDI plate.

The peptide mixtures were analyzed by $4800 \mathrm{MALDI}$ TOF/ TOF $^{\mathrm{TM}}$ Analyzer (Applied Biosystems, Foster City, CA, USA) with reflection/delayed extraction mode. After calibration with the trypsin-autodigested peaks, monoisotopic peptide masses were obtained with Data Explorer 4.4 software (Applied Biosystems). Peptide mass fingerprinting was processed with the MASCOT algorithm (Matrix Science, London, UK) to assign peptides in the NCBI non-redundant human genome database (NCBI nr).

Western blotting. The protein lysates were separated by one-dimensional SDS-PAGE electrophoresis. The resolved proteins were transferred onto the nitrocellulose membrane (Hybond $^{\mathrm{TM}}$-P; Amersham Bioscience, Piscataway, NJ, USA). The membrane was blocked with phosphate-buffered saline (PBS) containing $0.2 \%$ Tween-20 and 5\% non-fat dry milk, and then incubated with the primary antibodies such as mouse monoclonal anti-moesin (38/87) (dilution 1:2,000, Abcam, Cambridge, MA, USA), rabbit polyclonal anti-keratin 17 (dilution 1:2,000, Abcam) and mouse monoclonal anticarbonic anhydrase I (1:2,000, Abcam) antibodies, at $4^{\circ} \mathrm{C}$ overnight. After washing three times with Tris-buffered saline (TBS) containing $0.1 \%$ Tween-20, they were incubated with horseradish peroxidase-labeled secondary antibody (1:4,000, Perkin-Elmer, Waltham, MA, USA) for $1 \mathrm{~h}$. The membranes were again washed three times in TBS buffer containing $0.1 \%$ Tween-20, then incubated in ECL reagent (GE Healthcare) for $1 \mathrm{~min}$, and then exposed to X-ray film (Pierce, Rockford, IL, USA). Then the films were scanned and the intensity of protein expression was analyzed by a public domain Java image processing program, Image $\mathbf{J}$ (http://rsbweb.nih.gov/ij/index. html). Mouse monoclonal anti- $\beta$-actin was used as control to normalize the difference in loaded protein quantity.

Tissue microarray construction. To confirm the expression of the proteins identified by proteomic analysis, a total of 176 cases of surgically resected colorectal adenocarcinoma were retrieved from the Pathology File of Korea University Guro Hospital between January 2002 and December 2004. After reviewing the $\mathrm{H} \& \mathrm{E}$-stained slides, from each patient two 2-mm cores were harvested from representative areas of cancer and normal mucosa, respectively. Then the cores were transferred to a paraffin recipient block with a $0.5-\mathrm{mm}$ distance between the cores up to 30 cores per block, using the Tissue Arrayer (Beecher Instruments, Gene Micro-Array Technologies, Silver Spring, MD, USA).

Immunohistochemistry. Serial $4-\mu \mathrm{m}$ sections of the tissue microarray blocks were heat-dried on Silane-coated slides (Muto Pure Chemical Co., Ltd., Tokyo, Japan) at $60^{\circ} \mathrm{C}$ overnight. The slides were deparaffinized with xylene and 

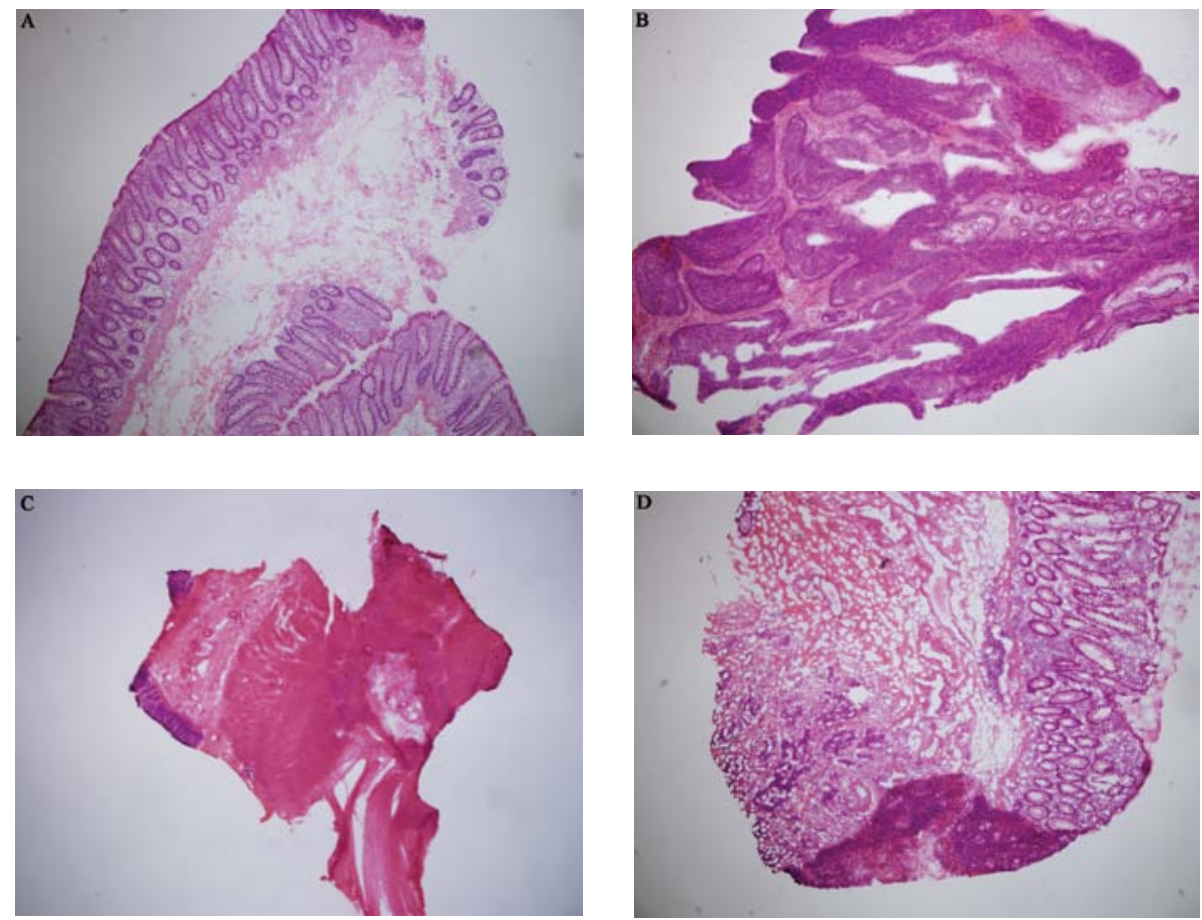

Figure 1. Cryostat sections of tumor and non-tumor samples. Adequate samples contain sufficient normal epithelial cells (A) or cancer cells (B) with no excessive necrosis, fibrosis or other unwanted tissue (magnification, $\mathrm{x} 40$ ). (C) Inadequate non-tumor samples contain insufficient normal epithelial cells and/ or excessive fibrosis and/or other unwanted tissues such as smooth muscle (magnification, x12.5). (D) Inadequate tumor sample consists of a small number of cancer cells and/or excessive non-tumor epithelium and stroma (magnification, $x 40$ ).

Table I. Clinicopathological characteristics of the patients submitted to protein analysis and identification.

\begin{tabular}{|c|c|c|c|c|c|c|c|c|}
\hline $\begin{array}{l}\text { Sample } \\
\text { no. }\end{array}$ & $\begin{array}{l}\text { Gender/ } \\
\text { Age }\end{array}$ & Histological type & Location & $\begin{array}{l}\text { Size } \\
(\mathrm{cm})\end{array}$ & $\begin{array}{c}\mathrm{pN} \\
\text { stage }^{\mathrm{a}}\end{array}$ & $\begin{array}{c}\mathrm{pT} \\
\text { stage }^{\mathrm{a}}\end{array}$ & $\begin{array}{l}\text { TNM } \\
\text { stage }^{a}\end{array}$ & $\begin{array}{l}\text { Astler-Coller } \\
\text { stage }\end{array}$ \\
\hline Tumor 1 & $\mathrm{M} / 62$ & Mucinous adenocarcinoma & Ascending colon & 6.7 & $\mathrm{pN} 1$ & pT4 & IIIB & $\mathrm{C} 3$ \\
\hline Tumor 2 & $\mathrm{M} / 57$ & Mucinous adenocarcinoma & Transverse colon & 9.0 & $\mathrm{pN} 1$ & pT4 & IIIB & $\mathrm{C} 3$ \\
\hline Tumor 3 & $\mathrm{M} / 48$ & Adenocarcinoma, moderately differentiated & Sigmoid colon & 4.5 & $\mathrm{pN} 2$ & pT4 & IIIB & $\mathrm{C} 3$ \\
\hline Tumor 4 & $\mathrm{~F} / 66$ & Adenocarcinoma, moderately differentiated & Rectum & 5.3 & pNO & pT4 & IIB & B3 \\
\hline
\end{tabular}

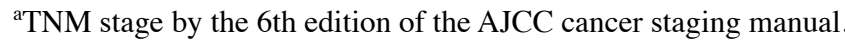

rehydrated in a graded alcohol series. They were placed in $10 \mathrm{mM}$ of citrate buffer (pH 6.0) and heated in a microwave for $5 \mathrm{~min}$ three times for antigen retrieval. They were then incubated with primary antibodies, i.e., anti-moesin (1:10,000, Abcam), and anti-keratin 17 (1:800, Abcam), for $30 \mathrm{~min}$ at room temperature. After a series of TBS rinse, the slides were incubated with biotinylated secondary antibody and diaminobenzidine substrate for $30 \mathrm{~min}$ according to the manual of a detection kit, Dako Envision ${ }^{\mathrm{TM}}+$ system (Dako, Glostrup, Denmark). Mayer's hematoxylin was used for counterstaining. As for carbonic anhydrase I protein, we could not find an antibody available for immunohistochemistry with formalin fixed paraffin-embedded tissue.

Immunohistochemical staining. Protein expression was evaluated by two pathologists, considering the staining intensity and proportion of positive cells. The moesin stain was considered positive when membrane and/or cytoplasm of epithelial cells were stained. The presence of moesin in mesenchymal cells was ignored in this study. The scoring was performed as follows: 0 , when no positive cells were present; 1 , when $<1 / 3$ of epithelial cells were weekly stained; 2 , when $1 / 3-2 / 3$ of epithelial cells were stained in weak to moderate intensity; 3 , when $>2 / 3$ of epithelial cells were stained in moderate to strong intensity (Fig. 3). The cytokeratin (KRT) 17 stain was also considered positive when membrane and/or cytoplasm of epithelial cells were stained and the cells were considered distinctly positive when they were stained in moderate to strong intensity. The scores of KRT17 were classified as follows: 0, when no positive cells were present; 1 , when $<25 \%$ of epithelial cells were stained distinctly in membrane or cytoplasm; 2 , when $<50 \%$ of epithelial cells were distinctly stained in membrane or cytoplasm; 3 , when $<75 \%$ of epithelial cells were distinctly stained in membrane or cytoplasm; 4 , when $<95 \%$ of epithelial cells were distinctly stained in membrane and cytoplasm; 5 , when $\geq 95 \%$ of epithelial cells were distinctly stained (Fig. 4). 
Statistical analysis. All statistical analyses were carried out using the SPSS version 15.0.1 for Windows (SPSS Inc., Chicago, IL, USA). The $\chi^{2}$ test or Fisher's exact test were used for determining the association between the immunohistochemical findings and the clinicopathological parameters. To determine whether there is a gradual change or a trend in protein expression according to the progression of $\mathrm{pT}, \mathrm{pN}, \mathrm{pM}$, and anatomic stage/prognostic group, linear by linear association $\chi^{2}$ tests were performed. P-values $<0.05$ were considered to indicate statistically significant differences.

\section{Results}

\section{Patients and samples}

Protein identification and Western blot analysis. The frozen tissue specimens were excluded from protein analysis in the following cases: i) the tumor sample was unsuitable for comparison with non-tumor sample because it contained a small number of actual tumor cells compared to muscle or other connective tissue components (Fig. 1); and ii) consistent 2-DE dispersion results suitable for analysis were unable to be obtained. In this study, only 4 of the 10 colorectal cancer specimens produced 2-DE gels suitable for subsequent image analysis and protein identification. They had been obtained from 3 men and 1 woman with an age range from 48 to 66 (mean 58.3) years, and histologically consisted of two moderately differentiated adenocarcinomas and two mucinous adenocarcinomas. Tumor locations were different in all 4 cases. The average tumor size was $5.7 \mathrm{~cm}$, and the stage was IIIB in 3 patients and IIB in 1 (Table I).

Tissue microarray (TMA) and immunohistochemistry. The clinicopathological characteristics of the 176 patients are summarized in Table II. The patients consisted of 98 men and 78 women. The mean age was 61.8 years with a range from 22 to 85 . The mean tumor size was $5.3 \mathrm{~cm}$. The tumors were located in the ascending colon $(n=49)$, transverse colon $(n=8)$, descending colon $(n=6)$, sigmoid colon $(n=9)$ and rectum $(n=104)$. Histologically, more than half of the tumors were moderately differentiated adenocarcinomas and the remainders were well or poorly differentiated adenocarcinomas and mucinous adenocarcinomas. None of the patients received chemotherapy or radiation before surgery. According to the 6th edition of AJCC staging system, there were 9 pT1, 31 pT2, 129 pT3 and 7 pT4 tumors, and 93 pN0, 49 pN1 and 34 pN2 tumors. Nineteen patients had metastatic lesions at the time of diagnosis. Combining the $\mathrm{T}, \mathrm{N}$, and $\mathrm{M}$ stages, the tumors were then grouped into the anatomic stage/prognostic groups as stage I ( $n=33)$, IIA ( $n=59)$, IIB ( $n=0)$, IIC ( $n=0)$, IIIA ( $n=6)$, IIIB $(n=39)$, IIIC $(n=20)$ and IV $(n=19)$.

Protein identification. The protein spots detected in the 2-DE gels ranged from 1053 to 1476 in number. The image analysis of scanned 2-DE gels by the ImageMaster 2-D platinum 6.0 program (GE Healthcare) revealed that 69 protein spots were differentially expressed in $\%$ volume (gap value $>0$ ) between the cancer and non-tumor mucosa groups. For protein identification, 13 spots out of the 69 with the greatest differences expressed as \% intensity were finally selected for mass spectrometry (Fig. 2).
Table II. Clinicopathological characteristics of patients submitted to tissue microarray and immunohistochemical analysis.

\begin{tabular}{lc}
\hline & $\mathrm{N}(\%)$ \\
\hline Age (years) & \\
Mean & 61.8 \\
Range & $22-85$ \\
Sex & \\
Male & $98(55.7)$ \\
Female & $78(44.3)$ \\
Tumor size (cm) & \\
Mean & \\
Range & 5.3 \\
\end{tabular}

Tumor location

Ascending colon

$49(27.8)$

Transverse colon

Descending colon

Sigmoid colon

Rectum

$104(59.1)$

Histological type

Tubular adenocarcinoma,

well differentiated

$118(67.0)$

moderately differentiated

poorly differentiated

Mucinous adenocarcinoma

pT stage

pT1

pT2

$31(17.6)$

pT3

$129(73.3)$

pT4

$\mathrm{pN}$ stage

pNO

$\mathrm{pN} 1$

$\mathrm{pN} 2$

TNM stage

I

$33(18.8$

IA

$59(33.5)$

IIIA

$6(3.4)$

IIIB

39 (22.2)

IIIC

20 (11.4)

IV

Each protein spot was processed with in-gel trypsin digestion. The extracted peptide solution was submitted to mass spectrometry [4800 MALDI TOF/TOF ${ }^{\mathrm{TM}}$ Analyzer (Applied Biosystems)] and the protein identification was accomplished using the Matrix Science search engine (http:// www.matrixscience.com) and selecting the highest MASCOT 


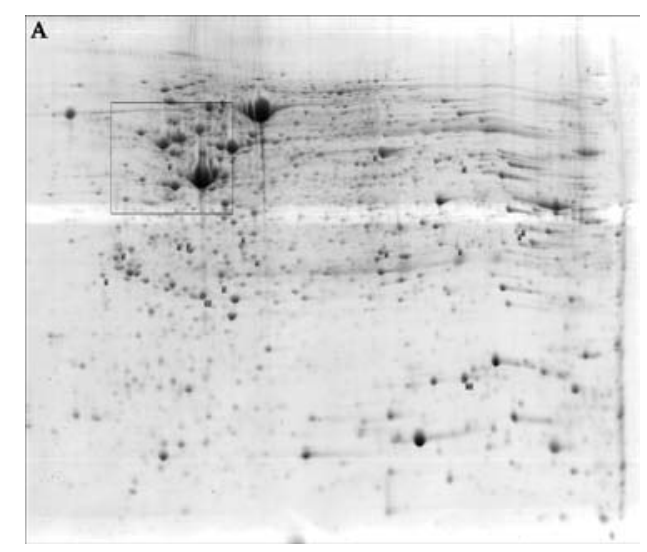

Figure 2. (A) The master 2-DE gel shows differentially expressed proteins between the colorectal carcinoma and the non-tumor mucosa. DryStrips $(24 \mathrm{~cm})(\mathrm{pI} 3-10)$ and large $12.5 \%$ SDS-PAGE gels $(24 \times 20 \mathrm{~cm})$ were used to analyze protein profiles. Protein spots were visualized by Coomassie blue stain. The inlet contains the spot identified as KRT17. To detect the differentially expressed proteins, each spot in non-tumor mucosa group (B) and colorectal carcinoma group (C) was compared to each other by ImageMaster 2-D Platinum 6.0 software.
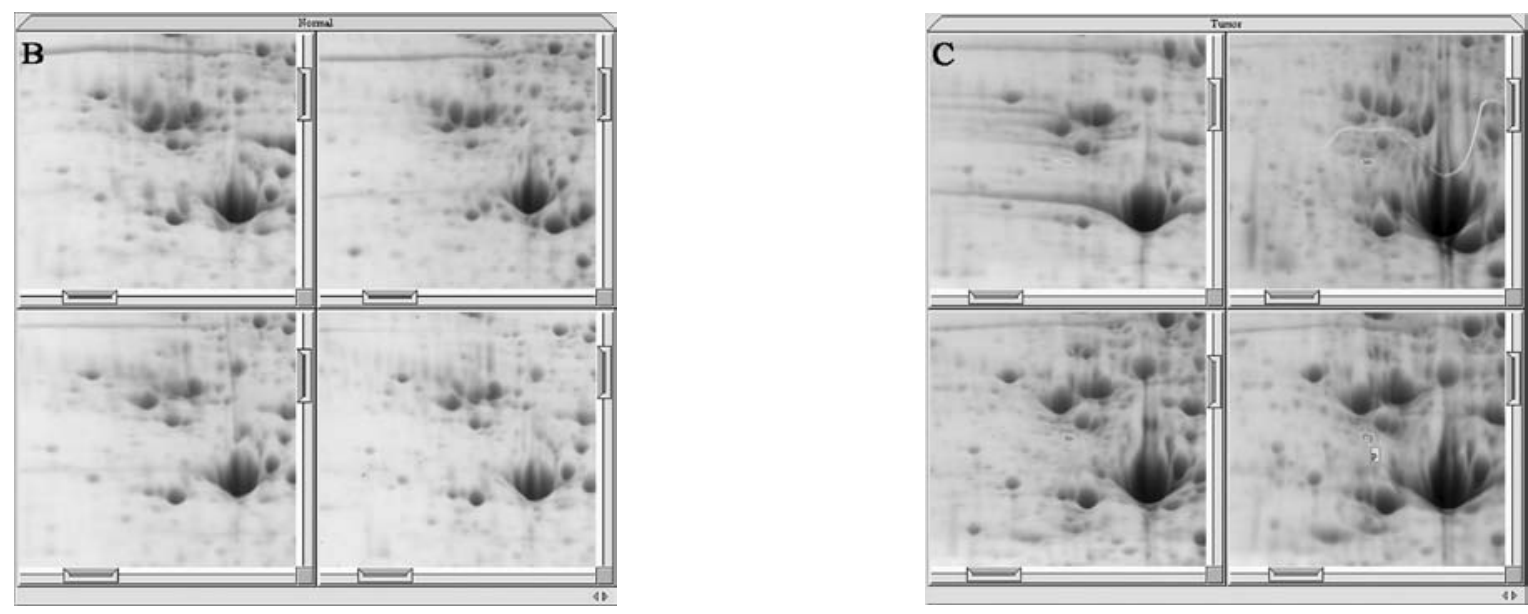

Table III. Identification of differentially expressed proteins between colorectal carcinoma and non-tumor mucosa.

\begin{tabular}{|c|c|c|c|c|c|c|}
\hline Protein name & $\begin{array}{l}\text { MASCOT } \\
\text { score }\end{array}$ & MW (Da) & PI & $\begin{array}{l}\text { MALDI-TOF/MS } \\
\% \text { Coverage }\end{array}$ & $\begin{array}{l}\text { Matched } \\
\text { peptide no. }\end{array}$ & $\begin{array}{l}\text { NCBI } \\
\text { accession no. }\end{array}$ \\
\hline $\begin{array}{l}\text { Chain A, moesin FERM domain bound } \\
\text { to Ebp50 C-terminal peptide }\end{array}$ & 169 & 35010 & 9.03 & 50 & 14 & gil50513540 \\
\hline $\begin{array}{l}\text { Chain A, human muscle fructose } \\
\text { 1,6-bisphosphate aldolase complexed } \\
\text { with fructose 1,6-bisphosphate }\end{array}$ & & 39720 & 8.39 & 40 & 10 & gil4557976 \\
\hline Cytokeratin (KRT) 17 & 148 & 40520 & 4.90 & 53 & 20 & gil47939651 \\
\hline $\begin{array}{l}\text { Porin } 31 \mathrm{HM} \text { (human, skeletal muscle } \\
\text { membranes, Peptide, } 282 \text { aa) }\end{array}$ & 135 & 30737 & 8.63 & 59 & 14 & gil238427 \\
\hline RAE1 (RNA export 1, S.pombe) homolog & 91 & 41569 & 7.96 & 41 & 14 & gil4506399 \\
\hline $\begin{array}{l}\text { Proteasome activator subunit } 1 \text { isoform } 1 \text {; } \\
\text { PA28 }\end{array}$ & 90 & 28876 & 5.78 & 46 & 13 & gil5453990 \\
\hline $\mathrm{p} 27 \mathrm{BBP}$ & 83 & 26845 & 4.56 & 62 & 10 & gil13785574 \\
\hline Tropomyosin 4 isoform 2 & 83 & 28619 & 4.67 & 44 & 10 & gil4507651 \\
\hline Cell division cycle 2 isoform $1 ; \mathrm{CDK} 1$ & 80 & 34131 & 8.37 & 46 & 13 & gil4502709 \\
\hline $\begin{array}{l}\text { Microtubule-associated protein, } \\
\text { RP/EB family, member 1;EB-1 }\end{array}$ & 77 & 30151 & 5.02 & 43 & 11 & gil6912494 \\
\hline C10ORF6 & 74 & 131868 & 9.08 & 20 & 16 & gil26225113 \\
\hline Ubiquitin carboxyl-terminal esterase L1 & 68 & 24808 & 5.33 & 45 & 10 & gil21361091 \\
\hline$\alpha$ II spectrin & 67 & 285689 & 5.22 & 12 & 23 & gil1805280 \\
\hline Carbonic anhydrase I & 80 & 28909 & 6.59 & 58 & 11 & gil4502517 \\
\hline
\end{tabular}



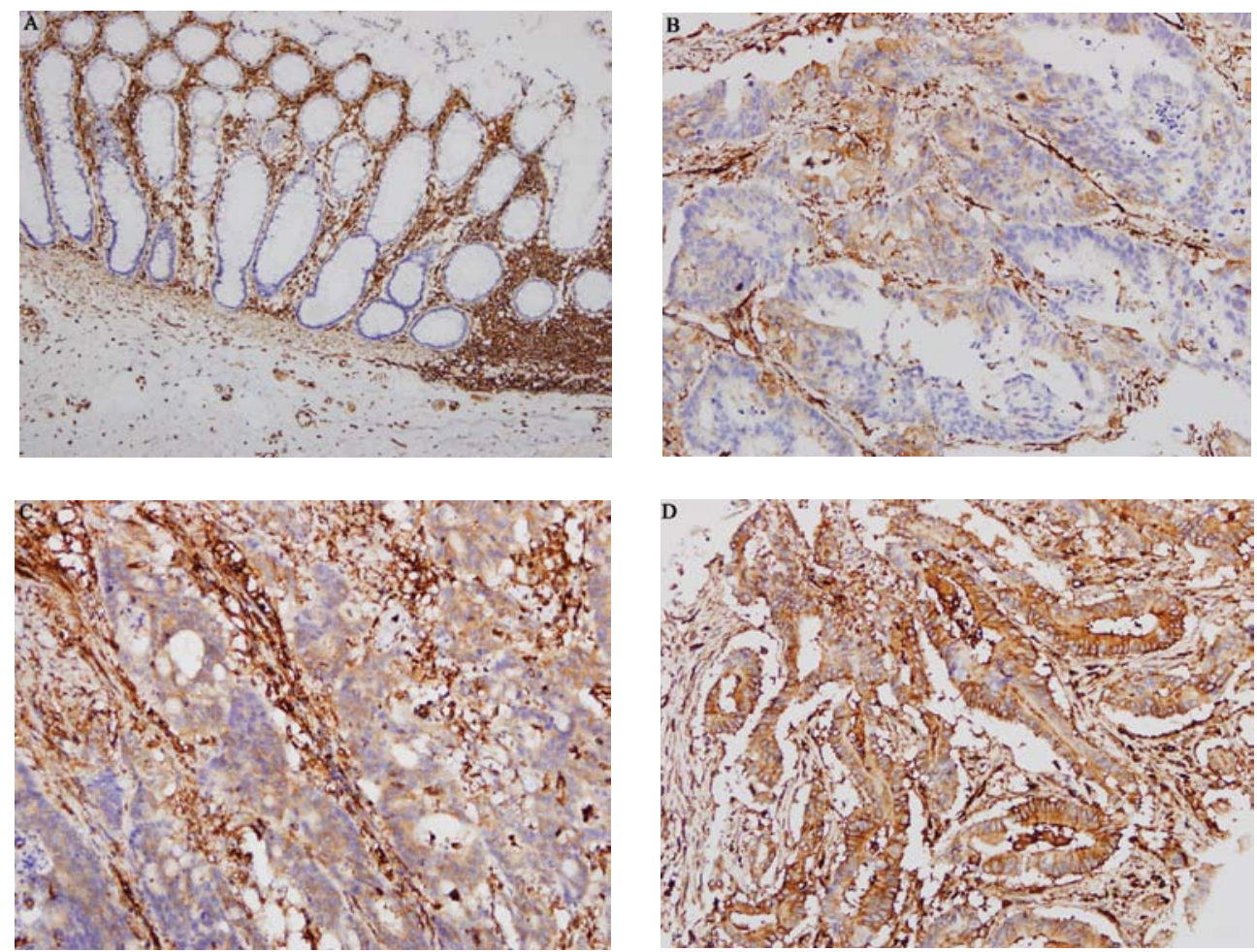

Figure 3. Moesin immunohistochemistry. (A) In normal colorectal mucosa, the mesenchymal cells are positive but the benign epithelial cells are completely negative for moesin (magnification, x 100). (B-D) In colorectal carcinoma, the malignant epithelial cells are positive for moesin as well as the mesenchymal cells (magnification, x200; B, score 1; C, score 2; D, score 3).
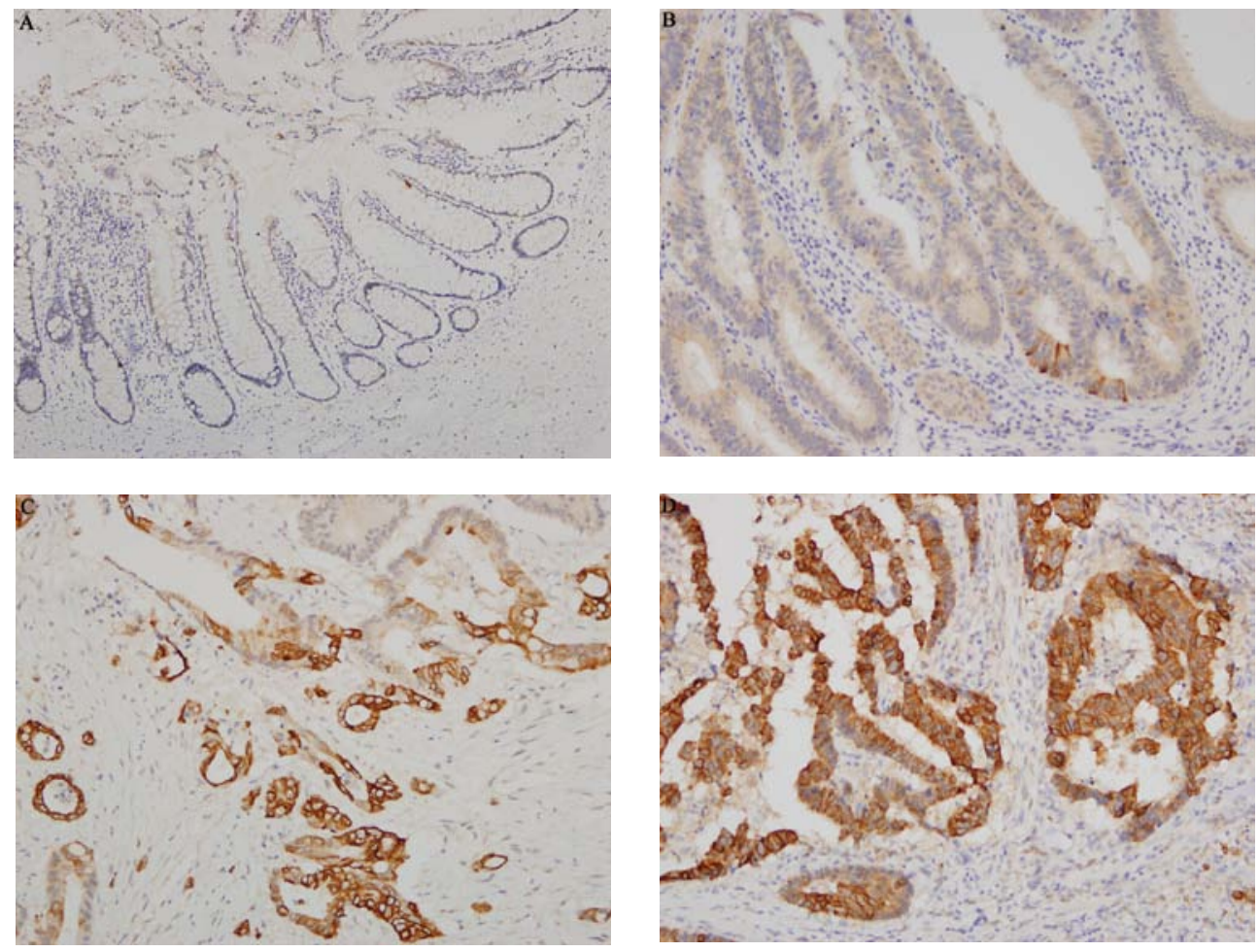

Figure 4. Cytokeratin 17 immunohistochemistry. (A) In normal colorectal mucosa, the benign epithelial cells are negative for CK17 (score 0) in all patients. (B-D) In colorectal carcinoma, the malignant cells are distinctly stained with CK17 in membrane and cytoplasm in variable proportion (magnification, x200; B, score 1 ; C, score 3; D, score 5).

score (Table III). Ten proteins showed MASCOT scores of over 75 with $95 \%$ significance $(\mathrm{p}<0.05)$. Among them, nine proteins including moesin FERM (EZrin-radixin-moesin- binding phosphoprotein) domain and Ebp50 complex (Chain $\mathrm{A}$, moesin ferm domain bound to Ebp50 C-terminal peptide), p27BBP, tropomyosin 4 isoform 2, proteasome activator 
A

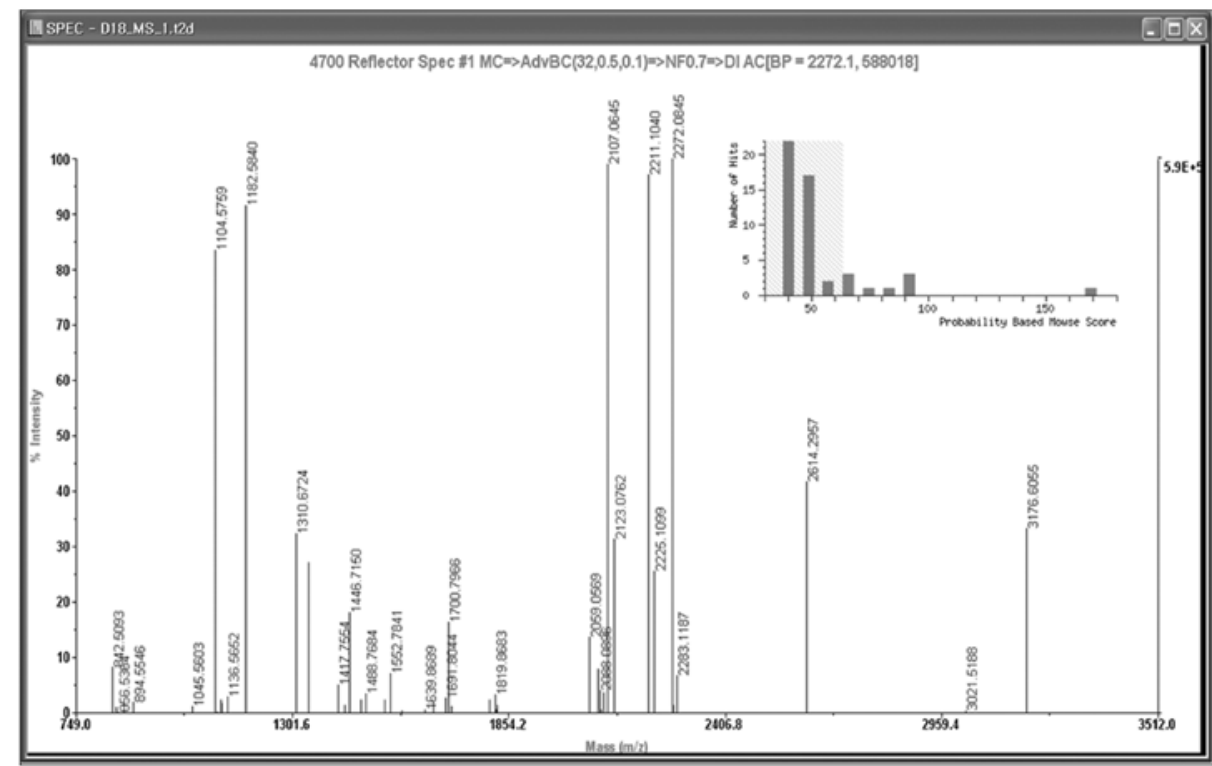

B

$\begin{aligned} 1 & \text { MPKTISVRVT } \\ \mathbf{5 1} & \text { DTKGFSTWLK } \\ 101 & \text { LFFLQVKEGI } \\ 151 & \text { KLLPQRVLEQ } \\ 201 & \text { YGVNYFSIKN } \\ 251 & \text { NDKKFVIKPI }\end{aligned}$

TMDAELEFAI
LNKKVTAQDV
LNDDIYCPPE
HKLNKDQWEE
KKGSELWLGV
DKKAPDFVFY

QPNTTGKQLF
RKESPLLFKF
TAVLLASYAV
RIQWWHEEHR
DALGLNIYEQ
APRLRINKRI

DQWKTIGLR
RAKFYPEDVS
QSKYGDFNKE
GMLREDAVLE
NDRLTPKIGF
LALCMGNHEL

\section{EVWFFGLQYQ \\ EELIQDITQR \\ VHKSGYLAGD \\ YLKIAQDLEM \\ PWSEIRNISF \\ YMRRRKP}

Figure 5. Protein identification by MALDI-TOF-MS analysis and MASCOT software. (A) The mass spectrum of a protein spot is obtained by MALDITOF-MS and the peak data are processed with the MASCOT algorithm. (B) Among 297 amino acids, 148 were matched (shown in bold) and the sequence coverage was $49.8 \%$.

subunit 1 isoform 1 (proteasome activator 28; PA28), REA1 (RNA export 1) homolog, cell division cycle isoforms 1 (cyclin-dependent kinase 1; CDK1), cytokeratin (KRT) 17, C10ORF6, microtubule-associated protein RP/EB family member 1 (End-binding protein 1; EB1), and porin $31 \mathrm{HM}$ (voltage-dependent anion-selective channel 1; VEAC1), were significantly increased in colorectal cancer compared to normal colorectal mucosa. Carbonic anhydrase I was the only protein which was decreased in cancer compared to normal mucosa (Table III). The protein identification data for moesin complexed with Ebp50 are presented in Fig. 5.

Western blotting. Of the 13 identified proteins, moesin, KRT17 and carbonic anhydrase I, which had fairly high MASCOT scores and easily obtainable commercial antibodies, were selected for validation by Western blotting. The intensity of KRT17 was significantly increased in 2 cancer samples than in normal mucosa while carbonic anhydrase I was more abundant in normal mucosa ( $n=3$ ) than in cancer (Fig. 6). However, moesin was hardly detectable in both cancer and normal mucosa and showed no distinct difference between the 2 groups.

Immunohistochemistry. A total of 176 cases of colorectal carcinoma and their paired normal mucosa were submitted to TMA construction to evaluate the protein expression by immunohistochemistry. In normal colorectal mucosa, moesin was not expressed in epithelial cells but present only in stromal fibroblasts and inflammatory cells. In colorectal carci-
A

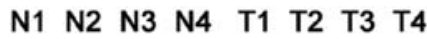

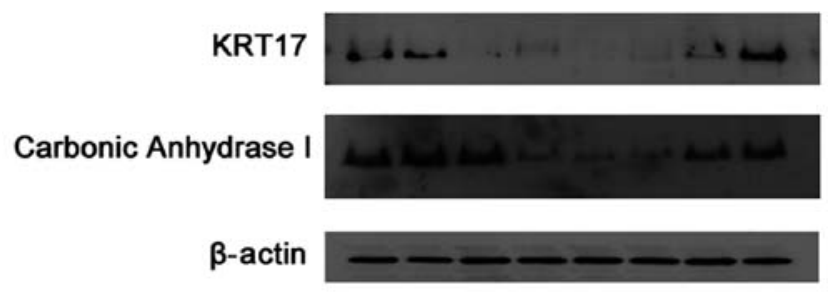

B

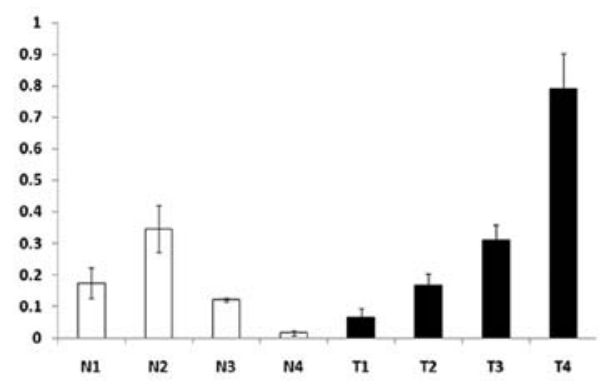

Figure 6. (A) Western blot anaylsis of KRT17 and carbonic anhydrase I in normal colorectal mucosa (N) and paired colorectal carcinoma (T). (B) The intensity of KRT17 was compared to the intensity of $\beta$-actin. The relative intensity of KRT17 in colorectal carcinoma was significantly higher in two cases (T3, T4).

noma, moesin was localized in the membrane and cytoplasm of tumor cells as well as in stromal cells and inflammatory 
Table IV. Moesin immunoreactivity in colorectal carcinomas.

\begin{tabular}{lcrrrr}
\hline & \multicolumn{5}{c}{ Tumor stage } \\
\cline { 2 - 6 } Immunoreactive score & pT1 & pT2 & pT3 & pT4 & Total \\
\hline 0 & 7 & 26 & 106 & 6 & 138 \\
1 & 2 & 3 & 9 & 0 & 14 \\
2 & 0 & 2 & 11 & 0 & 13 \\
3 & 0 & 0 & 3 & 1 & 4 \\
Total & 9 & 31 & 129 & 7 & 176 \\
\hline
\end{tabular}

Table V. KRT17 immunoreactivity in colorectal carcinomas.

\begin{tabular}{lcrrcc}
\hline & \multicolumn{5}{c}{ Tumor stage } \\
\cline { 2 - 6 } Immunoreactive score & pT1 & pT2 & pT3 & pT4 & Total \\
\hline 0 & 3 & 9 & 44 & 0 & 56 \\
1 & 3 & 12 & 40 & 5 & 60 \\
2 & 2 & 4 & 16 & 0 & 22 \\
3 & 1 & 3 & 13 & 1 & 18 \\
4 & 0 & 2 & 7 & 1 & 10 \\
5 & 0 & 1 & 9 & 0 & 10 \\
Total & 9 & 31 & 129 & 7 & 176 \\
\hline
\end{tabular}

cells. Thirty-one (17.6\%) colorectal cancers were positive with moesin immunoreactivity (Fig. 3) and an increasing tendency of moesin expression in cancer cells in relation to the advancement of $\mathrm{T}$ stage was observed although no statistical significance was proven ( $>0.05$ ) (Table IV). In contrast to moesin, KRT17 was expressed only in epithelial cells. In normal colorectal mucosa, KRT17 was negative in all cases. In colorectal carcinoma, KRT17 was reactive in malignant tumor cells in 120 cases (68.2\%) (Fig. 4). The intensity of KRT17 tended to increase in relation to the advancement of $\mathrm{T}$ stage (Table V). However, no statistical significance was observed (p>0.05). Interestingly, in 23 of 120 reactive cases (19.2\%), KRT17 reactivity seemed most strong in those cells present along the infiltrative growth front, forming angulated glands, irregular cell clusters or cords, or scattered single cells (Fig. 7), although no statistical significance was observed ( $>0.05$ ).

Neither moesin nor KRT17 immunoreactivity showed a significant association with other clinicopathological parameters, including patient's age and gender, lymph node status ( $\mathrm{N}$ stage) or distant metastasis ( $\mathrm{M}$ stage), histological subtype or grade, the final anatomic stage/prognostic group determined by T, N, and M stages, or survival. Carbonic anhydrase I was not evaluated immunohistochemically because we could not obtain an antibody.

\section{Discussion}

A proteomic approach was used in this study to find proteins overexpressed in primary colorectal carcinoma compared to
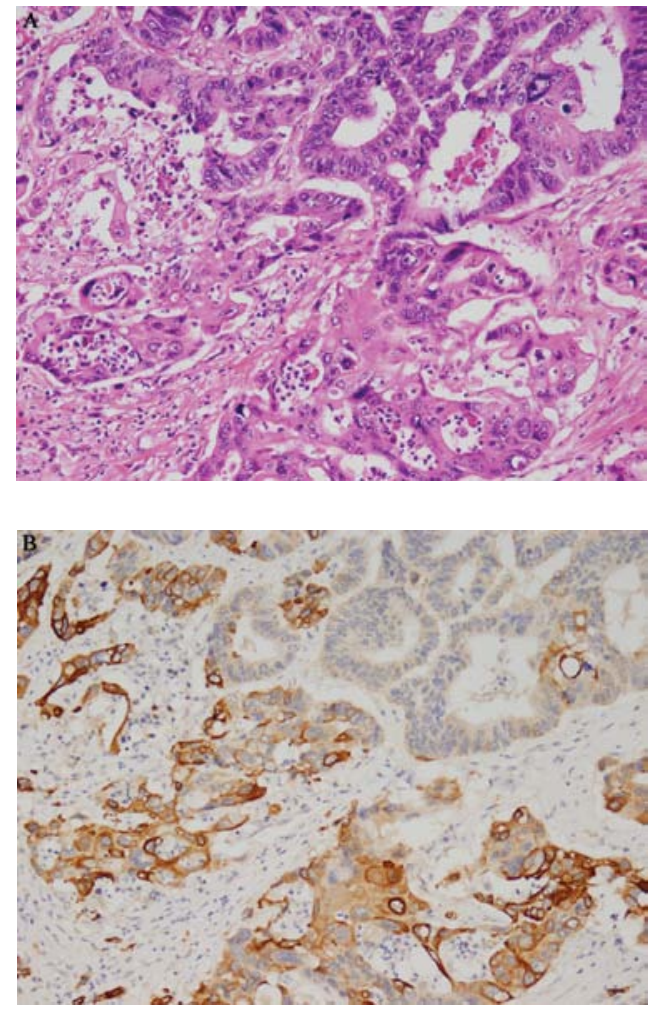

Figure 7. The KRT17 immunoreactivity is stronger in those cells irregularly infiltrating the stroma as invasive cellular cords or scattered single cells. (magnification, x200; A, H\&E; B, KRT17).

normal colorectal mucosa. To evaluate the protein expression and various clinicopathological characteristics, immunohistochemical examination of TMA was performed. The 2-DE and mass spectrometric identification revealed 12 up- and one down-regulated proteins in colorectal carcinomas (Table III). Of the 13 proteins, moesin, KRT17, and carbonic anhydrase I, which were with high MASCOT scores and available antibodies, were selected for further analysis and validation by Western blotting and immunohistochemistry.

Moesin, detected in this study in the form of moesin FERM (Ezrin-radixin-moesin-binding phosphoprotein) domain and Ebp50 complex (Chain A, moesin FERM domain bound to Ebp50 C-terminal peptide), are part of the ezrin-radixinmoesin (ERM) family of proteins, which are known to play a key role in the control of cell-surface morphology and also in cell signal relaying via connecting the membranous adhesion molecules such as interleukins, to the cytoplasmic actin cytoskeleton (29-33). Of the ERM family proteins, ezrin has been reported in many studies to be related to cancer progression and metastasis, thereby conferring poor prognosis (34-43). In contrast, studies reporting that moesin has a direct effect on tumor incidence or progression are relatively few in number. However, evidence supporting that moesin plays an important role in cancer behavior, especially in invasion and metastasis, have begun to accumulate. For example, Carmeci et al in their research using breast cancer cell lines reported that moesin expression was much higher in ER-negative breast cancer cells than in ER-positive cells and suggested that moesin may be involved in the invasiveness or metastatic potential characteristic of the ER-negative breast cancer phenotypes 
(44). Analyzing the gene expressions and copy numbers in uterine cervical cancers, Lyng et al reported that moesin gene expression was strongly associated with metastatic phenotypes of cervical cancer (45). In another study on cervical cancer metastasis, He et al demonstrated that the expression levels of moesin in surgically resected cancer tissue were significantly correlated with tumor malignancy and metastasis (46). In a proteomic profiling study by Cui et al, moesin expression was much higher in pancreatic cancer with lymph node metastasis than in tumor without metastasis (47). In a study using melanoma cell lines, Estecha et al have reported that moesin was crucial for invasion by melanoma cells in 3D matrices and early lung colonization by controlling adhesion-dependent activation of Rho and myosin II contractility (48). Although several studies have suggested that moesin is associated with aggressive behavior in various cancers, this study is, to our knowledge, the first evaluating its expression and possible role in colorectal carcinoma. In the present study, moesin expression was higher in colorectal cancer than in non-tumor mucosa. Although not proven statistically significant in the current study, the tendency of the increasing expression according to the $\mathrm{T}$ stage progression of tumor, may support the results of previous research suggesting that moesin may play an important role in cancer invasion and metastasis when further evaluated with larger numbers of subjects in each stage group. Besides, although moesin was expressed in connective tissues both of cancer and non-tumor specimens, its expression in epithelial cells was confined to cancer cells only, suggesting this molecule really has a specific function in carcinoma cells.

Cytokeratin (KRT) 17 is a protein usually present in the basal cells of stratified squamous epithelium or ductal epithelium. KRT17 has been considered a tumor marker in squamous cell carcinoma of head and neck and breast cancers $(49,50)$. Especially, in 'triple-negative' breast cancers in which ER, progesterone receptor (PR) and HER2 are all test-negative, KRT17 expression has been associated with a worse prognosis, high tumor grade and positive axillary lymph nodes (51-54). There has also been a report that KRT17 was suggested as the marker of a highly tumorigenic basal cell compartment in urothelial carcinoma (55). However, no remarkable results have been reported concerning the expression and/or function of KRT17 in colorectal cancer so far. In this study, we demonstrated increased KRT17 expression in colorectal cancer compared to normal colorectal mucosa by proteomic profiling, and confirmed it by immunohistochemistry of tissue microarray. Like moesin, KRT17 also showed a tendency of increased expression with advancement of T stage, although in this study statistical significance was not achieved.

Carbonic anhydrase I was the only protein that showed a significant decrease in expression in colorectal cancer tissue compared to normal mucosa. Although there have been reports of less-than-normal expression in squamous cell carcinomas of the head and neck, to date, no correlation has been made between this molecule and colorectal carcinoma (56). We were unable to obtain an available antibody for immunohistochemical analysis in TMA that will confirm the result in 2-DE analysis; however, by Western blot analysis, the expression of carbonic anhycrase I was lower in the colorectal cancer group than in the normal mucosa group. Further study with an immunohistochemistry-compatible antibody may support our result and suggest a correlation between this protein expression and other interesting clinicopathological parameters, including tumor stage or metastasis.

In the 2-DE experiment, both moesin and KRT17 was distinctly increased in colorectal cancer compared to nontumor mucosa. However, in Western blot analysis, their expression in cancer and non-tumor mucosa showed only a subtle or no difference. Such results could have been caused by a few reasons. First, the fresh-frozen tissues that were used in the Western blot analysis were not as good in quality and quantity as those used in 2-DE analysis. A great amount of well-preserved tissues was required to perform the 2-DE and protein identification. Thus, the tissues available for Western blot analysis were relatively small in amount and not as fresh as those used in earlier experiments. This is an inevitable obstacle in studies requiring human tissue. To overcome such an obstacle, research plans should be completed before collecting tissue specimens and much effort should be put into obtaining sufficient amounts of high-quality tissue in a great amount of time. Second, the formalin-fixed paraffin-embedded (FFPE) tissues used in immunohistochemistry may have quite different characteristics from those of the fresh-frozen tissues in Western blot analysis. Formalin fixation and subsequent tissue processing can add reactive radicals to macromolecules and induce various crosslinks within and between the molecules, resulting in the conformational changes of proteins and changes in antigen epitopes (57). The subsequent antigen retrieval process in immunohistochemistry may also have caused further changes in antigenicity. These changes in molecular structure and antigenicity may be one of reasons that cause the different results from the reactions with same antibodies.

Beside the above-mentioned three proteins, several other proteins showed a different expression between colorectal carcinomas and non-tumor mucosa tissues in 2-DE and were identified with a MASCOT sore $>75$ with $95 \%$ significance $(\mathrm{p}<0.05)$. Ebp50 (ezrin-radixin-moesin binding phosphoprotein of $50 \mathrm{kDA})$ or NHEFR1 $\left(\mathrm{Na}^{+} / \mathrm{H}^{+}\right.$exchanger regulating factor 1), discovered as bound to moesin FERM domain, has been known to bind to more than 30 proteins and play important roles in ion transport regulation, stabilization of transmembrane receptors, organization of apical microvilli, and regulation of cell signaling pathways related to cancer progression $(58,59)$. Ebp50 was proposed to act as a tumor suppressor when it is localized at the plasma membrane and as an oncogenic protein when localized in the cytoplasm (58). Ebp50 interacts with all three members of the ERM family. Although a significant in vivo functional connection has been found mainly between Ebp50 and ezrin so far (37-39,60-64), parallel expression of Ebp50 and moesin, with shifts in cellular distribution from membrane to cytoplasm, have also been reported to correlate with increasing invasiveness of oral squamous cell carcinoma (65). In our study, Ebp50 was detected as bound to moesin and expressed more highly in colorectal cancer than in non-tumor mucosa, thus suggesting that moesin and Ebp50 also play together a role in development and progression of colorectal carcinoma.

p27BBP interacts with integrin $\beta 4$ in epithelial cells to control ribosome assembly within the cytoplasm (66-68). p27BBP has been reported to be highly expressed in rapidly 
dividing cells, including colorectal adenoma and carcinomas, and in particular to be increased progressively from adenoma to carcinoma, and in the latter, to be related to tumor stage (66). Besides colon cancer, p27BBP has been reported to increase greatly in carcinoma of the head and neck, seemingly playing a significant role in the carcinogenic process (68).

Tropomyosins are actin-associated cytoskeletal proteins in muscle and non-muscle cells, with multiple isoforms $(69,70)$. Several isoforms of tropomyosins, the so-called low-molecular weight tropomyosins, which are composed of less than 248 residues, were reported to be associated with metastatic potential of several cancer cells, including melanoma, breast carcinoma, and lung cancer cells (71-73). Tropomyosin 4 is one of these low-molecular weight tropomyosins, and was reported to increase in esophageal squamous cell carcinoma compared to adjacent normal epithelium (74).

The proteasome is a $200,000-\mathrm{Da}$, multisubunit protease complex. It associates with a number of other protein complexes, which function as regulators of its activator (75). Proteasome activator 28 (PA28) is a protein activator of the $20 \mathrm{~S}$ proteasome and activates the proteasome's hydrolysis of small peptides, not related to the degradation of ubiquitinated proteins $(76,77)$. It has been suggested by Miyagi et al that a decreased expression of PA28 in colon cancer cells reduces HLA 1 protein expression, helping cancer cells avoid effects of the immune system (78). Giusti et al observed, through a proteomic method, that PA28 significantly increased in papillary carcinoma of the thyroid gland compared to normal tissue (79). In our study, PA28 was distinctly increased in resected colorectal carcinoma than in non-tumor mucosa. Whether this protein plays a specific role in development or progression of colorectal cancer requires further studies.

RAE1 is considered a critical protein for maintaining the biopolarity of mitotic spindles (80). Although there has been no clear evidence that RAE1 is directly related to cancer development, an unstable mitotic spindle leads to aberrant chromosome segregation during mitosis and chromosome instability, which has been proposed to cause tumor development and/or progression (81).

Cell division cycle 2 isoform 1 (cyclin-dependent kinase 1; CDK1), along with cyclin $\mathrm{B}$, was recently reported to promote phosphorylation of the anti-apoptotic proteins Bcl-xL and Bcl-2, disabling their anti-apoptotic activity, in cells experiencing mitotic arrests or sustained spindle checkpoint activation. CDK1 has been suggested to be the kinase responsible for the effects of microtubule inhibitors and other antimitotic agents that prolong the activation of this checkpoint $(82,83)$. It is not clear whether CDK1 plays a direct role in certain cancer development or progression.

End-binding protein 1 (EB-1) is a member of microtubule plus-end tracking proteins (+TIPs), which controls microtubule dynamics and participates in various microtubule-mediated cell activities, such as cell migration, division, and morphogenesis (84-86). Several recent studies suggest that EB-1 may be involved in carcinogenesis, too. For example, overexpression of EB-1 has been detected in hepatocellular carcinoma, gastric carcinoma, esophageal squamous cell carcinoma, and breast carcinoma (87-90). In breast carcinoma, Dong at al also proposed that EB-1 expression was correlated with higher histological grade, advanced pTNM stage, and more frequent lymph node metastasis (90). In this study, EB-1 was increased in colorectal carcinoma than in non-tumor mucosa. Adenomatous polyposis coli (APC) protein, a tumor suppressor in colorectal epithelium, is known as one of the interacting partners of EB-1 in microtubule dynamics and mitosis; however, whether EB-1 plays a direct role in cancer development requires further studies.

Voltage-dependent anion-selective channel 1 (VDAC1) is a pore-forming protein that exists in the outer mitochondrial wall and cell membrane. It adjusts cell oxidation-reduction reactions and participates in apoptosis through regulating the permeability of mitochondrial membrane under the influence of proapoptotic Bax and Bak proteins or antiapoptotic Bcl-xL protein $(91,92)$. VDAC1 has been reported to be overexpressed in several cancer cells $(93,94)$, however, the suggested roles of this molecules have been inconsistent in several studies. For example, in studies by Simamura et al, overexpression of VDAC1 in cancer cells was reported to increase the sensitivity of cancer cells to quinine antitumor drugs (93-95). On the other hand, Pan et al reported that VDAC1 was consistently increased at both the protein and the RNA levels in caboplatinand paclitaxel-resistant ovarian cancer (96). In another recent study, Koren et al suggested that VDAC1 promote cancer cell growth in animal models (97). To elucidate the roles of VDAC1 in various cancers, including the colorectal cancer in our study, further studies will be required.

In summary, using a proteomics approach we detected several interesting proteins including moesin and KRT17, which were significantly increased in colorectal cancer. Moesin and KRT17 has been proposed to play a role in cancer invasion, metastasis and poor prognosis in several cancers, and may also contribute to development and progression of colorectal cancer. Besides moesin and KRT17, several other proteins, also detected as elevated or reduced in colorectal cancer, has been suggested to participate in cancer behaviors, including cell proliferation, mobility, and invasion, in various cancers. Further studies in colorectal carcinoma may elucidate their role in the carcinogenesis and tumor behavior of colorectal cancer.

\section{References}

1. Yoon YS, Yu CS, Jung SH, et al: Characteristics of colorectal cancer detected at the Health Promotion Center. J Korean Soc Coloproctol 23: 321-326, 2007.

2. Calistri D, Rengucci C, Bocchini R, Saragoni L, Zoli W and Amadori D: Fecal multiple molecular tests to detect colorectal cancer in stool. Clin Gastroenterol Hepatol 1: 377-383, 2003.

3. Boynton KA, Summerhayes IC, Ahlquist DA and Shuber AP: DNA integrity as a potential marker for stool-based detection of colorectal cancer. Clin Chem 49: 1058-1065, 2003.

4. Dong SM, Traverso G, Johnson C, et al: Detecting colorectal cancer in stool with the use of multiple genetic targets. J Natl Cancer Inst 93: 858-865, 2001.

5. Ahlquist DA, Skoletsky JE, Boynton KA, et al: Colorectal cancer screening by detection of altered human DNA in stool: feasibility of a multitarget assay panel. Gastroenterology 119: 1219-1227, 2000.

6. Jonker DJ, O'Callaghan CJ, Karapetis CS, et al: Cetuximab for the treatment of colorectal cancer. N Engl J Med 357: 2040-2048, 2007.

7. Arnold D and Seufferlein T: Targeted treatments in colorectal cancer: state of the art and future perspectives. Gut 59: 838-858, 2010.

8. Ferrara N, Gerber HP and LeCouter J: The biology of VEGF and its receptors. Nat Med 9: 669-676, 2003. 
9. Ferrara N, Hillan KJ, Gerber HP and Novotny W: Discovery and development of bevacizumab, an anti-VEGF antibody for treating cancer. Nat Rev Drug Discov 3: 391-400, 2004.

10. Presta LG, Chen H, O'Connor SJ, et al: Humanization of an anti-vascular endothelial growth factor monoclonal antibody for the therapy of solid tumors and other disorders. Cancer Res 57: 4593-4599, 1997.

11. Summy JM and Gallick GE: Src family kinases in tumor progression and metastasis. Cancer Metastasis Rev 22: 337-358, 2003.

12. Talamonti MS, Roh MS, Curley SA and Gallick GE: Increase in activity and level of pp60c-src in progressive stages of human colorectal cancer. J Clin Invest 91: 53-60, 1993.

13. Tabernero J, Cervantes A, Hoekman K, et al: Phase I study of AZD0530, an oral potent inhibitor of Src kinase: first demonstration of inhibition of Src activity in human cancers. J Clin Oncol 25: 3520,2007

14. Tice DA, Biscardi JS, Nickles AL and Parsons SJ: Mechanism of biological synergy between cellular Src and epidermal growth factor receptor. Proc Natl Acad Sci USA 96: 1415-1420, 1999.

15. Abraham RT and Gibbons JJ: The mammalian target of rapamycin signaling pathway: twists and turns in the road to cancer therapy. Clin Cancer Res 13: 3109-3114, 2007.

16. Eichhorn PJ, Gili M, Scaltriti M, et al: Phosphatidylinositol 3-kinase hyperactivation results in lapatinib resistance that is reversed by the mTOR/phosphatidylinositol 3-kinase inhibitor NVP-BEZ235. Cancer Res 68: 9221-9230, 2008.

17. Serra V, Markman B, Scaltriti M, et al: NVP-BEZ235, a dual $\mathrm{PI} 3 \mathrm{~K} / \mathrm{mTOR}$ inhibitor, prevents PI3K signaling and inhibits the growth of cancer cells with activating PI3K mutations. Cancer Res 68: 8022-8030, 2008.

18. Chuthapisith S, Lay field R, Kerr ID and Eremin O: Principles of proteomics and its applications in cancer. Surgeon 5: 14-22, 2007.

19. Lievre A and Laurent-Puig P: Molecular biology in clinical cancer research: the example of digestive cancers. Rev Epidemiol Sante Publique 53: 267-282, 2005 (In French).

20. Srinivasula SM, Hegde R, Saleh A, et al: A conserved XIAPinteraction motif in caspase- 9 and Smac/DIABLO regulates caspase activity and apoptosis. Nature 410: 112-116, 2001.

21. Kuramitsu Y and Nakamura K: Proteomic analysis of cancer tissues: shedding light on carcinogenesis and possible biomarkers Proteomics 6: 5650-5661, 2006.

22. Moritz RL, Skandarajah AR, Ji H and Simpson RJ: Proteomic analysis of colorectal cancer: prefractionation strategies using two-dimensional free-flow electrophoresis. Comp Funct Genomics 6: 236-243, 2005.

23. Knox SJ, Goris ML, Tempero M, et al: Phase II trial of yttrium90-DOTA-biotin pretargeted by NR-LU-10 antibody/streptavidin in patients with metastatic colon cancer. Clin Cancer Res 6 : 406-414, 2000

24. Stulík J, Koupilova K, Osterreicher J, et al: Protein abundance alterations in matched sets of macroscopically normal colon mucosa and colorectal carcinoma. Electrophoresis 20: 3638-3646, 1999.

25. Lane CS, Nisar S, Griffiths WJ, et al: Identification of cytochrome P450 enzymes in human colorectal metastases and the surrounding liver: a proteomic approach. Eur J Cancer 40 2127-2134, 2004.

26. Dundas SR, Lawrie LC, Rooney PH and Murray GI: Mortalin is over-expressed by colorectal adenocarcinomas and correlates with poor survival. J Pathol 205: 74-81, 2005

27. Friedman DB, Hill S, Keller JW, et al: Proteome analysis of human colon cancer by two-dimensional difference gel electrophoresis and mass spectrometry. Proteomics 4: 793-811, 2004.

28. Alfonso P, Núñez A, Madoz-Gurpide J, Lombardia L, Sánchez L and Casal JI: Proteomic expression analysis of colorectal cancer by two-dimensional differential gel electrophoresis. Proteomics 5: 2602-2611, 2005

29. Sato N, Funayama N, Nagafuchi A, Yonemura S and Tsukita S: A gene family consisting of ezrin, radixin and moesin. Its specific localization at actin filament/plasma membrane association sites. J Cell Sci 103 (Pt 1): 131-143, 1992.

30. Bretscher A, Edwards K and Fehon RG: ERM proteins and merlin: integrators at the cell cortex. Nat Rev Mol Cell Biol 3 . 586-599, 2002.

31. Wei YC, Li CF, Yu SC, et al: Ezrin overexpression in gastrointestinal stromal tumors: an independent adverse prognosticator associated with the non-gastric location. Mod Pathol 22: 1351-1360, 2009.

32. Louvet-Vallee S: ERM proteins: from cellular architecture to cell signaling. Biol Cell 92: 305-316, 2000.
33. Tsukita S and Yonemura S: Cortical actin organization: lessons from ERM (ezrin/radixin/moesin) proteins. J Biol Chem 274: 34507-34510, 1999.

34. Li Q, Wu M, Wang H, et al: Ezrin silencing by small hairpin RNA reverses metastatic behaviors of human breast cancer cells. Cancer Lett 261: 55-63, 2008.

35. Kim MS, Cho WH, Song WS, Lee SY and Jeon DG: Prognostic significance of ezrin expression in pleomorphic malignant fibrous histiocytoma. Anticancer Res 27: 1171-1178, 2007.

36. Weng WH, Ahlen J, Astrom K, Lui WO and Larsson C: Prognostic impact of immunohistochemical expression of ezrin in highly malignant soft tissue sarcomas. Clin Cancer Res 11: 6198-6204, 2005.

37. Yu Y, Khan J, Khanna C, Helman L, Meltzer PS and Merlino G: Expression profiling identifies the cytoskeletal organizer ezrin and the developmental homeoprotein Six-1 as key metastatic regulators. Nat Med 10: 175-181, 2004

38. Khanna C, Wan X, Bose S, et al: The membrane-cytoskeleton linker ezrin is necessary for osteosarcoma metastasis. Nat Med 10: 182-186, 2004

39. Hunter KW: Ezrin, a key component in tumor metastasis. Trends Mol Med 10: 201-204, 2004.

40. Martin TA, Harrison G, Mansel RE and Jiang WG: The role of the CD44/ezrin complex in cancer metastasis. Crit Rev Oncol Hematol 46: 165-186, 2003

41. Harrison GM, Davies G, Martin TA, Jiang WG and Mason MD Distribution and expression of CD44 isoforms and Ezrin during prostate cancer-endothelium interaction. Int J Oncol 21: 935-940, 2002.

42. Ohtani K, Sakamoto H, Rutherford T, Chen Z, Satoh K and Naftolin F: Ezrin, a membrane-cytoskeletal linking protein, is involved in the process of invasion of endometrial cancer cells. Cancer Lett 147: 31-38, 1999.

43. Dransfield DT, Bradford AJ, Smith J, et al: Ezrin is a cyclic AMP-dependent protein kinase anchoring protein. EMBO J 16: 35-43, 1997.

44. Carmeci C, Thompson DA, Kuang WW, Lightdale N, Furthmayr $\mathrm{H}$ and Weigel RJ: Moesin expression is associated with the estrogen receptor-negative breast cancer phenotype. Surgery 124: 211-217, 1998.

45. Lyng H, Brovig RS, Svendsrud DH, et al: Gene expressions and copy numbers associated with metastatic phenotypes of uterine cervical cancer. BMC Genomics 7: 268, 2006.

46. He M, Cheng Y, Li W, et al: Vascular endothelial growth factor $\mathrm{C}$ promotes cervical cancer metastasis via up-regulation and activation of RhoA/ROCK-2/moesin cascade. BMC Cancer 10: 170,2010

47. Cui Y, Wu J, Zong M, et al: Proteomic profiling in pancreatic cancer with and without lymph node metastasis. Int J Cancer 124: 1614-1621, 2009.

48. Estecha A, Sanchez-Martin L, Puig-Kroger A, et al: Moesin orchestrates cortical polarity of melanoma tumour cells to initiate 3D invasion. J Cell Sci 122: 3492-3501, 2009.

49. Solassol J, Burcia V, Costes V, et al: Pemphigus vulgaris antigen mRNA quantification for the staging of sentinel lymph nodes in head and neck cancer. Br J Cancer 102: 181-187, 2010.

50. Toyoshima T, Koch F, Kaemmerer P, Vairaktaris E, Al-Nawas B and Wagner W: Expression of cytokeratin $17 \mathrm{mRNA}$ in oral squamous cell carcinoma cells obtained by brush biopsy: preliminary results. J Oral Pathol Med 38: 530-534, 2009.

51. Thike AA, Iqbal J, Cheok PY, et al: Triple negative breast cancer: outcome correlation with immunohistochemical detection of basal markers. Am J Surg Pathol 34: 956-964, 2010.

52. Rakha EA, Elsheikh SE, Aleskandarany MA, et al: Triplenegative breast cancer: distinguishing between basal and non-basal subtypes. Clin Cancer Res 15: 2302-2310, 2009.

53. Liu ZB, Wu J, Ping B, et al: Basal cytokeratin expression in relation to immunohistochemical and clinical characterization in breast cancer patients with triple negative phenotype. Tumori 95: 53-62, 2009.

54. Potemski P, Kusinska R, Watala C, Pluciennik E, Bednarek AK and Kordek R: Prognostic relevance of basal cytokeratin expression in operable breast cancer. Oncology 69: 478-485, 2005.

55. He X, Marchionni L, Hansel DE, et al: Differentiation of a highly tumorigenic basal cell compartment in urothelial carcinoma. Stem Cells 27: 1487-1495, 2009.

56. Ralhan R, Desouza LV, Matta A, et al: Discovery and verification of head-and-neck cancer biomarkers by differential protein expression analysis using iTRAQ labeling, multidimensional liquid chromatography, and tandem mass spectrometry. Mol Cell Proteomics 7: 1162-1173, 2008. 
57. Dapson RW: Macromolecular changes caused by formalin fixation and antigen retrieval. Biotech Histochem 82: 133-140, 2007.

58. Georgescu MM, Morales FC, Molina JR and Hayashi Y: Roles of NHERF1/EBP50 in cancer. Curr Mol Med 8: 459-468, 2008.

59. Voltz JW, Weinman EJ and Shenolikar S: Expanding the role of NHERF, a PDZ-domain containing protein adapter, to growth regulation. Oncogene 20: 6309-6314, 2001.

60. Iwadate Y, Sakaida T, Hiwasa T, et al: Molecular classification and survival prediction in human gliomas based on proteome analysis. Cancer Res 64: 2496-2501, 2004.

61. Moilanen J, Lassus H, Leminen A, Vaheri A, Butzow R and Carpen O: Ezrin immunoreactivity in relation to survival in serous ovarian carcinoma patients. Gynecol Oncol 90: 273-281, 2003.

62. Makitie T, Carpen O, Vaheri A and Kivela T: Ezrin as a prognostic indicator and its relationship to tumor characteristics in uveal malignant melanoma. Invest Ophthalmol Vis Sci 42: 2442-2449, 2001

63. Tokunou M, Niki T, Saitoh Y, Imamura H, Sakamoto M and Hirohashi S: Altered expression of the ERM proteins in lung adenocarcinoma. Lab Invest 80: 1643-1650, 2000.

64. Akisawa N, Nishimori I, Iwamura $\mathrm{T}$, Onishi $\mathrm{S}$ and Hollingsworth MA: High levels of ezrin expressed by human pancreatic adenocarcinoma cell lines with high metastatic potential. Biochem Biophys Res Commun 258: 395-400, 1999.

65. Kobayashi H, Sagara J, Masumoto J, Kurita H, Kurashina K and Taniguchi S: Shifts in cellular localization of moesin in normal oral epithelium, oral epithelial dysplasia, verrucous carcinoma and oral squamous cell carcinoma. J Oral Pathol Med 32 : 344-349, 2003.

66. Sanvito F, Vivoli F, Gambini S, et al: Expression of a highly conserved protein, $\mathrm{p} 27 \mathrm{BBP}$, during the progression of human colorectal cancer. Cancer Res 60: 510-516, 2000

67. Biffo S, Sanvito F, Costa S, et al: Isolation of a novel beta4 integrin-binding protein (p27(BBP)) highly expressed in epithelial cells. J Biol Chem 272: 30314-30321, 1997.

68. Rosso P, Cortesina G, Sanvito F, et al: Overexpression of p27BBP in head and neck carcinomas and their lymph node metastases. Head Neck 26: 408-417, 2004

69. Lin JJ, Helfman DM, Hughes SH and Chou CS: Tropomyosin isoforms in chicken embryo fibroblasts: purification, characterization, and changes in Rous sarcoma virus-transformed cells. J Cell Biol 100: 692-703, 1985 .

70. Cote GP: Structural and functional properties of the non-muscle tropomyosins. Mol Cell Biochem 57: 127-146, 1983.

71. Miyado K, Kimura M and Taniguchi S: Decreased expression of a single tropomyosin isoform, TM5/TM30nm, results in reduction in motility of highly metastatic B16-F10 mouse melanoma cells. Biochem Biophys Res Commun 225: 427-435, 1996.

72. Franzen B, Linder S, Uryu K, et al: Expression of tropomyosin isoforms in benign and malignant human breast lesions. Br J Cancer 73: 909-913, 1996.

73. Takenaga K, Nakamura Y and Sakiyama S: Differential expression of a tropomyosin isoform in low- and high-metastatic Lewis lung carcinoma cells. Mol Cell Biol 8: 3934-3937, 1988.

74. Qi Y, Chiu JF, Wang L, Kwong DL and He QY: Comparative proteomic analysis of esophageal squamous cell carcinoma. Proteomics 5: 2960-2971, 2005.

75. Song X, Mott JD, von Kampen J, et al: A model for the quaternary structure of the proteasome activator PA28. J Biol Chem 271: 26410-26417, 1996.

76. Dubiel W, Pratt G, Ferrell K and Rechsteiner M: Purification of an $11 \mathrm{~S}$ regulator of the multicatalytic protease. J Biol Chem 267: 22369-22377, 1992 .

77. Dubiel W, Ferrell K, Pratt G and Rechsteiner M: Subunit 4 of the $26 \mathrm{~S}$ protease is a member of a novel eukaryotic ATPase family. J Biol Chem 267: 22699-22702, 1992.

78. Miyagi T, Tatsumi T, Takehara T, et al: Impaired expression of proteasome subunits and human leukocyte antigens class I in human colon cancer cells. J Gastroenterol Hepatol 18: 32-40, 2003 .
79. Giusti L, Iacconi P, Ciregia F, et al: Fine-needle aspiration of thyroid nodules: proteomic analysis to identify cancer biomarkers. J Proteome Res 7: 4079-4088, 2008.

80. Nakano H, Funasaka T, Hashizume C and Wong RW: Nucleoporin translocated promoter region (Tpr) associates with dynein complex, preventing chromosome lagging formation during mitosis. J Biol Chem 285: 10841-10849, 2010.

81. Rao CV, Yamada HY, Yao Y and Dai W: Enhanced genomic instabilities caused by deregulated microtubule dynamics and chromosome segregation: a perspective from genetic studies in mice. Carcinogenesis 30: 1469-1474, 2009.

82. Terrano DT, Upreti M and Chambers TC: Cyclin-dependent kinase 1-mediated Bcl-xL/Bcl-2 phosphorylation acts as a functional link coupling mitotic arrest and apoptosis. Mol Cell Biol 30: 640-656, 2010

83. Nakayama S, Torikoshi Y, Takahashi T, et al: Prediction of paclitaxel sensitivity by CDK 1 and CDK2 activity in human breast cancer cells. Breast Cancer Res 11: R12, 2009.

84. Akhmanova A and Steinmetz MO: Tracking the ends: a dynamic protein network controls the fate of microtubule tips. Nat Rev Mol Cell Biol 9: 309-322, 2008.

85. Morrison EE: Action and interactions at microtubule ends. Cell Mol Life Sci 64: 307-317, 2007.

86. Vaughan KT: TIP maker and TIP marker; EB1 as a master controller of microtubule plus ends. J Cell Biol 171: 197-200, 2005.

87. Fujii K, Kondo T, Yokoo H, Yamada T, Iwatsuki K and Hirohashi S: Proteomic study of human hepatocellular carcinoma using two-dimensional difference gel electrophoresis with saturation cysteine dye. Proteomics 5: 1411-1422, 2005.

88. Nishigaki R, Osaki M, Hiratsuka M, et al: Proteomic identification of differentially-expressed genes in human gastric carcinomas. Proteomics 5: 3205-3213, 2005.

89. Wang Y, Zhou X, Zhu H, et al: Overexpression of EB1 in human esophageal squamous cell carcinoma (ESCC) may promote cellular growth by activating beta-catenin/TCF pathway. Oncogene 24: 6637-6645, 2005.

90. Dong X, Liu F, Sun L, et al: Oncogenic function of microtubule end-binding protein 1 in breast cancer. J Pathol 220: 361-369, 2010.

91. Shimizu S, Narita M and Tsujimoto Y: Bcl-2 family proteins regulate the release of apoptogenic cytochrome $\mathrm{c}$ by the mitochondrial channel VDAC. Nature 399: 483-487, 1999.

92. Narita M, Shimizu S, Ito T, et al: Bax interacts with the permeability transition pore to induce permeability transition and cytochrome c release in isolated mitochondria. Proc Natl Acad Sci USA 95: 14681-14686, 1998.

93. Simamura E, Shimada H, Ishigaki Y, Hatta T, Higashi N and Hirai K: Bioreductive activation of quinone antitumor drugs by mitochondrial voltage-dependent anion channel 1. Anat Sci Int 83: 261-266, 2008

94. Simamura E, Hirai K, Shimada H, Koyama J, Niwa Y and Shimizu S: Furanonaphthoquinones cause apoptosis of cancer cells by inducing the production of reactive oxygen species by the mitochondrial voltage-dependent anion channel. Cancer Biol Ther 5: 1523-1529, 2006.

95. Simamura E, Shimada H, Hatta T and Hirai K: Mitochondrial voltage-dependent anion channels (VDACs) as novel pharmacological targets for anti-cancer agents. J Bioenerg Biomembr 40: 213-217, 2008

96. Pan S, Cheng L, White JT, et al: Quantitative proteomics analysis integrated with microarray data reveals that extracellular matrix proteins, catenins, and p53 binding protein 1 are important for chemotherapy response in ovarian cancers. OMICS 13: 345-354, 2009.

97. Koren I, Raviv Z and Shoshan-Barmatz V: Downregulation of voltage-dependent anion channel-1 expression by RNA interference prevents cancer cell growth in vivo. Cancer Biol Ther 9: 1046-1052, 2010. 